\title{
Factors Inspiring the Emergence of Women Entrepreneurs in Sylhet City
}

\author{
Mohammad Kamrul Ahsan \\ Assistant Professor \\ Department of Business Administration \\ Metropolitan University, Sylhet, Bangladesh \\ Email: ahsan404243@gmail.com \\ Obidulla Raju \\ Lecturer \\ Department of Business Administration \\ Metropolitan University, Sylhet, Bangladesh
}

\begin{abstract}
This is basically a descriptive research paper. This research paper investigates the motivational factors among the women entrepreneurs of Sylhet City in Bangladesh. The main objective of this paper is to find out the cause of why they are in the field of entrepreneurs. The results of this paper will help researchers who are working in the field of entrepreneurs and motivations. The data were collected from the 68 women entrepreneurs from the different parts of Sylhet City. For this purpose, the structured closed-end questionnaire and random sampling method are used to collect the data. The researchers have used simple descriptive statistics, regression analysis and percentage to present the results with the help of Microsoft Excel 2016. This study discovered that self-recognition and economic necessities are the major factors to become entrepreneurs for them.
\end{abstract}

Keywords: Entrepreneur, Entrepreneurship, Women Entrepreneurs, Motivational Factors.

\section{Introduction}

Entrepreneurship as the way toward conceptualizing, sorting out, propelling and through development, supporting a business opportunity into a conceivably high development adventure in an intricate and unsteady condition (Rwigema \& Venter, 2004).An entrepreneur or a business person is one who sorts out, oversees and accepts the danger of a business undertaking (Herrington et al., 2009). Whenever a female owns a business, manages a business, and bears risk to run the business then she called a woman entrepreneur. Buttner \& Moore (1997) defines that a woman entrepreneur preserves at least 50 percent of the firm and that the business has been in action one year or longer.

This is basically a descriptive research paper. The aim of this paper is to express the causes why the women in Sylhet city come into entrepreneurships. The study area of this paper is Sylhet city which is north-east part of Bangladesh. There are huge causes of women entrepreneurships all over the world. It is very simple that all the causes will not be present here. By the discussion of several women entrepreneurs and scholars, the researchers have taken thirteen variables for this research purposes. All the causes can be divided into two sides: i) Push causes and

ii) Pull causes. Push causes actually related to the matters of survive whereas pull causes are related to the matters for using opportunities of their skills. All these two causes are present in the Sylhet city.

The structure of this paper contains six parts. The first part contains simple some definitions of entrepreneurs, entrepreneurship and female entrepreneurs entitled as an introduction. The second part contains the research questions, research objectives, and research hypothesis. The third part contains research methods, limitations and previous scholars" opinions regarding the influencing factors of women entrepreneurs. The fourth part contains the conceptual framework and research model for this study. The fifth part contains the analysis and findings, and the sixth part contains conclusions and references.

\subsection{Research Question}

What are the variables that influence women to become an entrepreneur?

\subsection{Research Objective}

To identify the major variables that influence women to become an entrepreneur in Sylhet City.

\subsection{Research Hypothesis}

$\mathrm{H}_{\mathrm{I}}$ : There is a weighty relationship between the motivational factors of women and their engagement of entrepreneurship in Sylhet City. 


\section{Research Methods}

\subsection{Research Design}

The study follows Descriptive research design. The study designates the variables that inspire women to become entrepreneurs.

\subsection{Population}

The target population of this study was the women entrepreneurs who are doing their business in Sylhet city.

\subsection{Sampling Method}

This study tracked the random sampling method to represent the population.

\subsection{Sample Size}

The study was conducted with 68 samples from the different parts of the Sylhet city.

\subsection{Data collection tool}

A survey instrument was developed to capture the information relating to the research objectives. A structured questionnaire was prepared in English and translated into the Bengali language, which is the national language of Bangladeshi people, for the purpose of interviewing women entrepreneurs in the Sylhet city which is the north-east part of the country. Questionnaires were delivered by hand by one of the researchers to the women-owned micro and small businesses. The questionnaire has two parts: i) biographical information of the participating women entrepreneurs, and ii) motivational factors for starting their businesses. To find out the cause of women entrepreneurs, thirteen variables have been considered as independent variables and only one variable is considered as a dependent variable that is "The Engagement of Entrepreneurship of Women". These variables are rated by Five Points Likert Scale. These are I=Strongly Dissatisfied, 2=Dissatisfied, 3=Average, 4=Satisfied, 5=Strongly Satisfied.

\subsection{Statistical analysis}

To verify the collected data several statistical analyses i.e., Descriptive statistics, Multiple Regression Analysis and percentage analysis has been conducted with the help of Microsoft Excel 2016 The researchers have used a 5\% level of significance.

The researcher has referred to various books, journals, and periodicals as the vital source of secondary data.

\section{Limitations of the Research}

There are some limitations to this study. They are:

- Most of the women entrepreneurs were busy in their respective works. So, they provide the least time to fill up the questionnaire.

- They were busy, so it may show misleading results.

- Different persons have different observations in the same matter.

- Some of the women were reluctant to provide data.

- Most of the women in Sylhet city were conservative, so, for the male researchers, it is difficult to collect data from them.

\section{Literature Review}

There are huge causes that influence men and women to be an entrepreneur. All the causes are two types: Push factors and pull factors.

\begin{tabular}{ll}
\hline $\begin{array}{l}\text { Push factors are those factors that relate to } \\
\text { necessities: }\end{array}$ & $\begin{array}{l}\text { Pull factors are those factors that related to skills } \\
\text { and entrepreneurial opportunities: }\end{array}$ \\
\hline $\begin{array}{l}\text { (I) unemployment, } \\
\text { (2) redundancy, }\end{array}$ & (I) need for independence, \\
\hline (3) recession, & $(3)$ need for a challenge, \\
\hline (4) inadequate family income, & $(4)$ self-fulfillment, \\
\hline (5) dissatisfaction with the current job, & $(5)$ desire to be own boss, \\
\hline (6) the need to accommodate work and home roles. & $(6)$ elasticity for balancing family and work, \\
\hline & (8) personal success (to be counted in the society), \\
\hline & $(7)$ potential to develop a hobby, \\
\hline & (9) role models and another people s influence \\
(Ismail, et al. 20I2).
\end{tabular}

According to ILO (2003), some women jump a business for the financial purpose to cover family wants while other women jump the business for using their career; sympathetic of the business; and to improve their lifestyles.

Hisrich \& Brush (1986) reported that the essence of female entrepreneurship is being driven by their need for independence, job fulfilment, need for success, money, status, control, financial insufficiency and job security. 
Lee (1997) states that women's choice of becoming business owners is particularly influenced by their emotional needs, i.e., motivated by a higher essential for achievement and supremacy.

Charles \& Gherman (2013) suggest that (a) personal growth, (b) social mission and (c) interpersonal relationships, represent the most vital factors prompting women's entrepreneurial choice.

Pandey (2013) found that education is a positive booster in motivating women to venture into entrepreneurship. Women "s family obligations also bar them from becoming successful entrepreneurs in both developed and developing nation. So, a woman entrepreneur should be provided support from the family as it is a very important motivating factor for them.

Afrin et. al. (2008) found that the details and inspirations for starting a business or economic movement by women are massive. The important reasons for starting a new commercial are: earning better life, influence of victory stories, personal gratification, desire to utilize own skills and talents, negative present working environment, self- employment and employment of others, assurance of carrier and family security, fulfillment of creative urge of the borrower "es, experience in family business, selfconfidence, non-ability to find suitable job or work, encouragement and advice of the family members, economic necessity and so on.

Azad (1982) reveals that the main motivating features for women entrepreneurs are an economic pressure, the occurrence of knowledge and skills, need for achievement, stimulus gathered from the success of others and blocking in the present occupation. Behara \& Niranjan (20I2) revealed the major factors prompting the women entrepreneur are economic freedom, establishing their own inspired idea, establishing their own identity, achievement of excellence, building confidence, developing the risktaking ability, motivation and equal status in society.

Moore (2003) finds that no single factor motivates women to become an entrepreneur. Ladies entrepreneurs refer to various explanations behind getting to be business visionaries. The persuading factor for lady's business people incorporates difficulties/attractions of enterprise, self-assurance/self-rule, family concerns, an absence of professional success and the longing to make a social commitment.

Rahim, et al (2017) found that several factors that have driven women entrepreneurs involved in entrepreneurship, those are: family support, family foundation, free factors, intrigue, instruction, work understanding, smugness, to accomplish desire, inspiration, to change family fortunes and different elements which are probably going to wind up a wellspring of salary support for those engaged with an enterprise.

On the basis of the previous study, the researchers formulate a conceptual framework.

Figure I: Conceptual Framework

\begin{tabular}{|c|c|}
\hline & $\begin{array}{c}\text { Independent } \\
\text { Variables }\end{array}$ \\
\hline 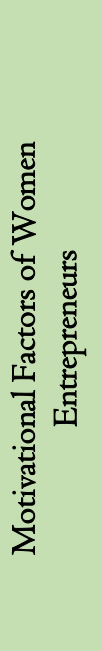 & $\begin{array}{l}\text { 1. To continue the family business } \\
\text { 2. To remove unemployment } \\
\text { 3.Family encouragement } \\
\text { 4. To increase my income } \\
\text { 5. There is the market for my product (service) } \\
\text { 6.For my own satisfaction and growth with publi } \\
\text { recognition } \\
\text { 7. Accessibility to personal finance to start a } \\
\text { business } \\
\text { 8. To be able to use my past experience and } \\
\text { training } \\
\text { 9. To run my family with economic solvency } \\
\text { 10. To maintain my personal freedom } \\
\text { 11. To prove myself that I can do it } \\
\text { 12. To build a business to pass the time } \\
\text { 13. Use of idle funds }\end{array}$ \\
\hline
\end{tabular}

Source: Authors" compilation, 2019

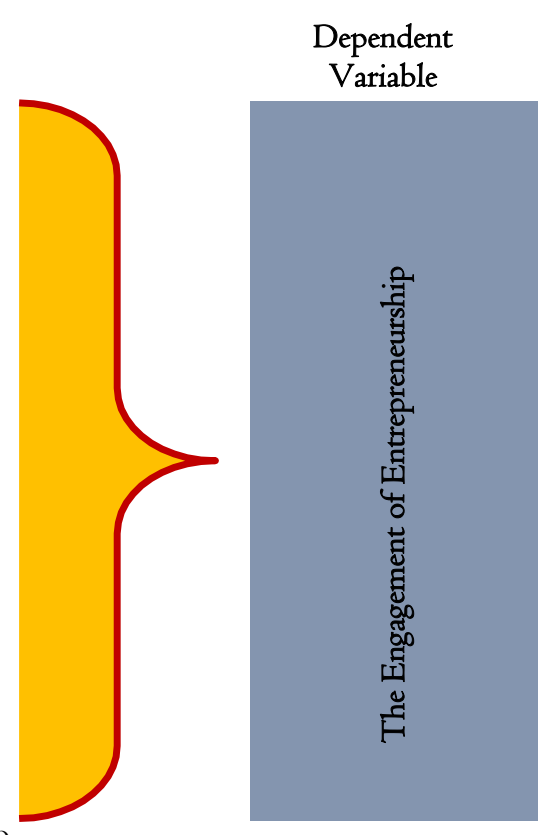

The conceptual framework shows how independent variables (motivational factors) hypothetically affect the dependent variable (engagement of entrepreneurship). On the basis of this conceptual framework, the researchers formulated a hypothesis. This formulated hypothesis is given the following.: 
$\mathrm{H}_{\mathrm{r}}$ : There is a weighty relationship between the motivational factors of women and their engagement of entrepreneurship in Sylhet City.

\section{Research Model}

Now the researchers have decided to know the significant impact of these motivational variables on the engagement of entrepreneurship of women in Sylhet city. For this reason, researchers decided to conduct a multiple regression analysis. The regression model for the study is as follows-

$\mathrm{EEW}=\alpha+\beta_{\mathrm{I}} \mathrm{X}_{\mathrm{I}}+\beta_{2} \mathrm{X}_{2}+\beta_{3} \mathrm{X}_{3}+\beta_{4} \mathrm{X}_{4}+\beta_{5} \mathrm{X}_{5}+\beta_{6} \mathrm{X}_{6}+\beta_{7} \mathrm{X}_{7}+\beta_{8} \mathrm{X}_{8}+\beta_{9} \mathrm{X}_{9}+\beta_{\mathrm{I} 0} \mathrm{X}_{\mathrm{I} 0}+\beta_{\mathrm{II}} \mathrm{X}_{\mathrm{II}}+\beta_{\mathrm{I} 2} \mathrm{X}_{\mathrm{I} 2}+\beta_{\mathrm{I} 3} \mathrm{X}_{\mathrm{I} 3}+C_{\mathrm{t}}$
Where,

EEW = The Engagement of Entrepreneurship of Women $\mathrm{X}_{\mathrm{I}}=$

To continue the family business

$\mathrm{X}_{2}=$ To remove unemployment

$\mathrm{X}_{3}=$ Family encouragement

$\mathrm{X}_{4}=$ To increase my income

$\mathrm{X}_{5}=$ There is the market for my product (service)

$\mathrm{X}_{6}=$ For my own satisfaction and growth with public recognition $\mathrm{X}_{7}=$

Accessibility to personal finance to start a business

$\mathrm{X}_{8}=$ To be able to use my past experience and training $\mathrm{X}_{9}$

$=$ To run my family with economic solvency

$\mathrm{X}_{\mathrm{IO}}=$ To maintain my personal freedom $\mathrm{X}_{\mathrm{II}}$

$=$ To prove myself that $I$ can do it $\mathrm{X}_{12}=\mathrm{To}_{\mathrm{o}}$

build a business to pass the time $\mathrm{X}_{\mathrm{I} 3}=$ Use of

idle funds

$\epsilon_{t}=$ Error Term

And $\alpha$ is a constant and $\beta_{1}, \beta_{2}, \beta_{3}, \beta_{4}, \beta_{5}, \beta_{6}, \beta_{7}, \beta_{8}, \beta_{9}, \beta_{10}, \beta_{11}, \beta_{12}, \beta_{13}$, are coefficient to estimate.

6. Analysis and Findings

Table No. 2: Demographic Profile

\begin{tabular}{|c|c|c|c|}
\hline S. No. & Demographic Profile & Number & Percentage \\
\hline \multirow[t]{7}{*}{$\mathrm{I}$} & Age Groups & & \\
\hline & Less than 20 & 0 & $0.00 \%$ \\
\hline & 21 to 30 & 3 & $4.41 \%$ \\
\hline & 31 to 40 & 26 & $38.24 \%$ \\
\hline & 41 to 50 & 39 & $57.35 \%$ \\
\hline & Over 50 & 0 & $0.00 \%$ \\
\hline & Total & 68 & $100 \%$ \\
\hline \multirow[t]{8}{*}{2} & Education & & \\
\hline & Below SSC & 4 & 5.88 \\
\hline & SSC & 9 & 13.24 \\
\hline & HSC & II & 16.18 \\
\hline & Bachelor & 23 & 33.82 \\
\hline & Masters & $2 \mathrm{I}$ & 30.88 \\
\hline & Others & 0 & 0.00 \\
\hline & Total & 68 & 100 \\
\hline \multirow[t]{6}{*}{3} & Religious & & \\
\hline & Muslim & 65 & 95.59 \\
\hline & Hindu & $\mathrm{I}$ & 1.47 \\
\hline & Christian & 0 & 0.00 \\
\hline & Buddhists & 2 & 2.94 \\
\hline & Others & 0 & 0.00 \\
\hline
\end{tabular}




\begin{tabular}{|c|c|c|c|}
\hline & Total & 68 & 100 \\
\hline \multirow[t]{5}{*}{4} & Marital Status & & \\
\hline & Married & 63 & 92.65 \\
\hline & Unmarried & 5 & 7.35 \\
\hline & Widow & 0 & 0.00 \\
\hline & Total & 68 & 100 \\
\hline \multirow[t]{7}{*}{5} & Family Members & & \\
\hline & $\mathrm{I}-2$ & 12 & 17.65 \\
\hline & $3-4$ & $4 \mathrm{I}$ & 60.29 \\
\hline & $5-6$ & I0 & $\mathrm{I} 4.7 \mathrm{I}$ \\
\hline & $7-8$ & 5 & 7.35 \\
\hline & Over 8 & 0 & 0.00 \\
\hline & Total & 68 & 100 \\
\hline \multirow[t]{7}{*}{6} & Members Depend on You & & \\
\hline & $\mathrm{I}-2$ & 57 & 83.82 \\
\hline & $3-4$ & II & 16.18 \\
\hline & $5-6$ & 0 & 0.00 \\
\hline & $7-8$ & 0 & 0.00 \\
\hline & Over 8 & 0 & 0.00 \\
\hline & Total & 68 & 100 \\
\hline \multirow[t]{7}{*}{7} & Rank Your Family Support & & \\
\hline & Very strong & 39 & 57.29 \\
\hline & Strong & 24 & 35.29 \\
\hline & Average & 5 & 7.35 \\
\hline & Low support & 0 & 0.00 \\
\hline & Very low support & 0 & 0.00 \\
\hline & Total & 68 & 100 \\
\hline \multirow[t]{6}{*}{8} & Problems Faced Starting Business & & \\
\hline & Managing family & 0 & 0.00 \\
\hline & Acquiring capital & $\mathrm{I} 4$ & 20.59 \\
\hline & Selection place & 35 & 51.47 \\
\hline & Others & I9 & 27.94 \\
\hline & Total & 68 & 100 \\
\hline \multirow[t]{4}{*}{9} & Type of Business & & \\
\hline & Sole proprietorship & 60 & 88.24 \\
\hline & Partnership & 8 & I I.76 \\
\hline & Total & 68 & 100 \\
\hline
\end{tabular}

Source: Authors" calculation based on field data, 2019

From table 2, it is seen that most of the entrepreneurs in Sylhet city are at the age of $4 \mathrm{I}$ to 50 (57.35\%). Most of them are married (92.65\%), Muslims (95.59\%), have a bachelor degree (33.82\%) and master se degree (30.88\%).

Most of the women entrepreneurs have the sole proprietorship business (88.24\%) and family members 3 to 4 (60.29\%) and $83.82 \%$ have dependent persons of I to 2 on them. But they get very strong support from their family 
$57.29 \%$. That is a very positive side of women entrepreneurs in Sylhet city in Bangladesh. That 's why they face problems to select the place (5I.47\%) where they will start their business.

Table No. 3: Descriptive Statistics

\begin{tabular}{|c|c|c|c|}
\hline S. No. & $\begin{array}{llll}\text { Motivational } & \text { Variables of } & \text { Women } \\
\text { Entrepreneurs } & & & \\
\end{array}$ & Mean & $\begin{array}{l}\text { Standard } \\
\text { Deviation }\end{array}$ \\
\hline $\mathrm{I}$ & To continue the family business & 3.43 & 0.17 \\
\hline 2 & To remove unemployment & 3.25 & 0.14 \\
\hline 3 & Family encouragement & 3.07 & 0.15 \\
\hline 4 & To increase my income & 3.26 & 0.17 \\
\hline 5 & There is the market for my product (service) & 3.53 & 0.16 \\
\hline 6 & $\begin{array}{l}\text { For my own satisfaction and growth with } \\
\text { public recognition }\end{array}$ & 3.32 & 0.14 \\
\hline 7 & $\begin{array}{l}\text { Accessibility to personal finance to start a } \\
\text { business }\end{array}$ & 3.34 & 0.15 \\
\hline 8 & $\begin{array}{l}\text { To be able to use my past experience and } \\
\text { training }\end{array}$ & 3.32 & 0.15 \\
\hline 9 & To run my family with economic solvency & 3.16 & 0.14 \\
\hline $\mathrm{IO}$ & To maintain my personal freedom & 3.40 & 0.15 \\
\hline II & To prove myself that I can do it & 3.32 & 0.15 \\
\hline 12 & To build a business to pass the time & 3.09 & 0.14 \\
\hline $\mathrm{I3}$ & Use of idle funds & 2.99 & 0.13 \\
\hline $\mathrm{I4}$ & $\begin{array}{l}\text { I Happy to Become a Woman Entrepreneur } \\
\text { (Dependent Variable) }\end{array}$ & 3.12 & 0.14 \\
\hline & Valid N & 68 & \\
\hline
\end{tabular}

Source: Authors" calculation based on field data, 2019

More average and less standard deviation indicate a more important factor. Here, it is seen that there is a market for service and product is the most important variable for women to be an entrepreneur. Later on, to continue the family business and personal freedom are the main causes for women to be entrepreneurs in Sylhet city.

Table No. 4: Regression Model Summary

\begin{tabular}{ll}
\hline \multicolumn{1}{c}{ Regression Statistics } \\
\hline Multiple R & 0.982 \\
\hline R Square & 0.964 \\
\hline Adjusted R Square & 0.956 \\
\hline Standard Error & 0.242 \\
\hline Observations & 68 \\
\hline
\end{tabular}

Source: Authors" calculation based on field data, 2019

From table 4 , it is seen that there is a significant correlation between dependent and independent variables. At the level of $5 \%$ significant, the correlation is $98.2 \%$, which shows an excellent relation because $\mathrm{R}$ is over 0.85 . The value of $\mathrm{R}$ Square indicates that $96.4 \%$ dependent variable is explained by the independent variables. Here its value is 0.964 , which shows the model is very good in shape. Remaining variance can be explained by the other variables. 
Table No. 5: Analysis of Variance Analysis (ANOVA)

\begin{tabular}{cccccc}
\hline ANOVA & \multicolumn{6}{c}{ S } & & & \\
\hline & $d f$ & $S S$ & Significance $F$ \\
\hline Regression & 13.000 & 85.884 & 6.606 & I I2.35 I & 0.000 \\
\hline Residual & 54.000 & 3.175 & 0.059 & & \\
\hline Total & 67.000 & 89.059 & & & \\
\hline
\end{tabular}

Source: Authors" calculation based on field data, 2019

ANOVA output indicates that the regression equation is explaining a statistically significant portion of the variability in the dependent variable from the variability of independent variables. This table also tells that the regression model is statistically significant $(\mathrm{p}=0.000$ which is $\mathrm{p}<0.05)$. Another way, it can be said that F-test is highly significant. It indicates that the hypothesis is proved, i.e., " $\mathrm{H}_{\mathrm{r}}$ : There is a significant relationship between the motivational factors of women and their engagement of entrepreneurship in Sylhet City." Hence ANOVA output supports the research hypothesis that there is a statistically significant relationship between the set of independent variables and dependent variables.

Table No. 6: Summary of Estimates

\begin{tabular}{|c|c|c|c|c|}
\hline & Coefficients & $\begin{array}{c}\text { Standard } \\
\text { Error }\end{array}$ & t Stat & P-value \\
\hline Intercept & $-0.12 \mathrm{I}$ & $0.13 \mathrm{I}$ & -0.920 & 0.362 \\
\hline $\mathrm{X}_{\mathrm{I}}$ & -0.016 & 0.033 & -0.487 & 0.628 \\
\hline $\mathrm{X}_{2}$ & 0.034 & 0.037 & 0.913 & 0.365 \\
\hline $\mathrm{X}_{3}$ & 0.026 & 0.031 & 0.830 & 0.410 \\
\hline $\mathrm{X}_{4}$ & 0.016 & 0.032 & 0.498 & 0.621 \\
\hline $\mathrm{X}_{5}$ & 0.025 & 0.032 & 0.797 & 0.429 \\
\hline $\mathrm{X}_{6}$ & 0.080 & 0.043 & 1.874 & 0.066 \\
\hline $\mathrm{X}_{7}$ & -0.033 & 0.040 & -0.816 & 0.418 \\
\hline $\mathrm{X}_{8}$ & -0.057 & 0.038 & $-\mathrm{I} .5 \mathrm{I} 4$ & 0.136 \\
\hline $\mathrm{X}_{9}$ & -0.004 & 0.041 & -0.109 & $0.9 \mathrm{I3}$ \\
\hline $\mathrm{X}_{\mathrm{IO}}$ & -0.040 & $0.04 \mathrm{I}$ & -0.963 & 0.340 \\
\hline $\mathrm{X}_{\mathrm{II}}$ & 0.026 & 0.045 & 0.576 & 0.567 \\
\hline $\mathrm{X}_{\mathrm{I} 2}$ & 1.018 & 0.040 & 25.725 & 0.000 \\
\hline$\overline{X_{13}}$ & -0.029 & 0.040 & -0.722 & 0.473 \\
\hline
\end{tabular}

Source: Authors" calculation based on field data, 2019

From the table 6, it is seen that, first column shows the independent variables and Second column shows the value of estimates. The first variable (constant) represents the constant, also referred to intercept. The regression equation is presented in this way:

$\mathrm{EEW}=-0.12 \mathrm{I}+(-0.016) \mathrm{X}_{\mathrm{I}}+(0.034) \mathrm{X}_{2}+(0.026) \mathrm{X}_{3}+(0.016) \mathrm{X}_{4}+(0.025) \mathrm{X}_{5}+(0.080) \mathrm{X}_{6}+(-0.033)+(-0.057) \mathrm{X}_{8}+$ $(-0.004) \mathrm{X}_{9}+(-0.040) \mathrm{X}_{\mathrm{I} 0}+(0.026) \mathrm{X}_{\mathrm{II}}+(\mathrm{I} .018) \mathrm{X}_{\mathrm{I} 2}+(-0.029) \mathrm{X}_{\mathrm{I} 3}+\mathrm{Ct}_{\mathrm{t}}$

7. Conclusion

Entrepreneurship is the process of creating own work. Whenever women take entrepreneurship is called the women entrepreneur. In this paper, there has an objective, to find out the cause of why they are in the field of 
entrepreneurship in Sylhet city. The findings tell that there is a market for service and product is the most important variable for women to be an entrepreneur. Later on, to continue the family business and personal freedom are the main causes for women to be entrepreneurs in Sylhet city. The most interesting matter that in Sylhet city, women entrepreneurs have strong family supports. Although there have some limitations of this paper, i.e., it is difficult to collect data from the women entrepreneurs in Sylhet city for the male researchers. After all, everything is fine for this research paper because the research model is very good in shape.

\section{References}

Afrin, S., Islam. N., \& Ahmed, S. U. (2008). A Multivariate Model of Micro-credit and Rural Women Entrepreneurship Development in Bangladesh, International Joumal of Business and Management, 3(8):I69-I85.

Azad, G.S. (1982), "Development of Entrepreneurship among Indian Women: A Psychological Analysis”, SEDME, Vol. I6

Behara, S. R., \& Niranjan, K. (2012). Rural woman Entrepreneurship in India, International Journal of Computational Engineering \& Management, I5 (6): 6-I5.

Buttner, E. H., \& Moore, D. P. (I997) Women 's organizational exodus to entrepreneurship: Self-reported motivations and correlates with success. Joumal of Small Business Management, 35(I): 34-46.

Charles, V., \& Gherman, T. (2013). Factors Influencing Peruvian Women to Become Entrepreneurs, World Applied Sciences Journal ,27 (I0), DOI: I0.5829/idosi.wasj.2013.27.10.464

Herrington, Mike, Kew, Jacqui, Kew, \& Penny. (2009). Global Entrepreneurship Monitor, South African Report. Available: http://www. GBS.nct.ac.za/gbswebb/user files/gemsouthafrica 2000pdf

Hisrich, R. D., \& Brush, C. (1986). The woman entrepreneur: Starting, financing and managing a successful new business. Toronto, Canada: Lexington Books, D. C. Heath, and Company.

ILO. (2003). Ethiopian Women entrepreneurs: Going for growth. Jobs, gender and small business in Africa. Pp 73- 8I.

Ismail, H. C., Shamsudin, F. M., \& Chowdhury, M. S. (2012). An Exploratory Study of Motivational Factors on Women Entrepreneurship Venturing in Malaysia, Business and Economic Research, 2(I):I-I3

Lee, J. (1997). The motivation of women entrepreneurs in Singapore, International Journal of Entrepreneurial Behaviour and Research, 3(2): 93-II0.

Moore, D. P. (2003). Women: Are You Ready to Be Entrepreneurs? Business \& Economic Review, 49(2): I5-2I.

Pandey, V. (2013). Factors Influencing Entrepreneurial Motivation of Women Entrepreneurs: A Case study with special reference to Lucknow District of Uttar Pradesh, BVIMSR's Journal of Management Research, 5 (2): I0I-I08

Rahim, I. H. A., Fabeil, N. F., \& Sung, T. P. (2017). Motivator and Challenges of Women Entrepreneurs, Journal of Global Business and Social Entrepreneurship, I (3): I I I-I2 I

Rwigema, H., \& Venter, R. (2004). Advanced Entrepreneurship. Cape Town: Oxford University Press Southern Africa.

\section{Copyrights}

Copyright for this article is retained by the author(s), with first publication rights granted to the journal.

This is an open-access article distributed under the terms and conditions of the Creative Commons Attribution license (http://creativecommons.org/licenses/by/4.0/) 